\title{
ANALISIS PENERIMAAN INFORMASI PENGGUNA WEBSITE DENGAN MENGGUNAKAN TECHNOLOGY ACCEPTANCE MODEL (STUDI KASUS : dpmd.inhilkab.go.id)
}

\author{
Dwi Yuli Prasetyo \\ Program Studi Sistem Informasi, Fakultas Teknik dan Ilmu Komputer, Universitas Islam Indragiri \\ Email: dwiyuliprasetyo@gmail.com
}

\begin{abstract}
This study aims to predict the acceptance of information from DPMD website users by using the Technology Acceptance Model approach with the TAM construct, namely perceived usefulness, perceived ease of use and attitude toward using. This study is a quantitative study using a causal research design that aims to obtain causal evidence between research variables consisting of perceived ease of use, perceived usefulness and attitude toward using. The results showed that the people of Indragiri Downstream District rated the DPMD website as relatively easy and beneficial because the news displayed was very accurate, valid and of high quality. The attitude of the community using the DPMD Website is that users feel happy because it can provide many benefits and users enjoy using the website. The ease of use of the DPMD website and the benefits of using the website of the indragiri hilir district community and village empowerment service simultaneously have a significant effect on user attitudes in using the website. The ease of use of the website and the benefits in using the website of the indragiri hilir district community and village empowerment service partially have a significant effect on user attitudes in using the DPMD website. The variable that has a dominant influence on user attitudes in using the DPMD website is the ease of using the website.
\end{abstract}

Keywords: website, DPMD, indragiri hilir, TAM, information

\begin{abstract}
Abstrak
Penelitian ini bertujuan untuk memprediksi penerimaan informasi pengguna website DPMD dengen menggunakan pendekatan model penerimaan teknologi (Technology Acceptance Model) dengan konstruk TAM yaitu kegunaan persepsian (perceived usefulness), kemudahan penggunaan persepsian (perceived ease of use) dan sikap pengguna teknologi (attitude toward using). Penelitian ini adalah penelitian kuantitatif dengan menggunakan rancangan penelitian kausal yang bertujuan untuk mendapatkan bukti sebab akibat antara variabel-variabel penelitian yang terdiri atas perceived ease of use, perceived usefulness dan attitude toward using. Hasil penelitian menunjukkan masyarakat kabupaten indragiri hilir menilai website DPMD relatif tidak sulit dan memberikan manfaat karena berita yang ditampikan sangat akurat, valid dan bermutu. Sikap dari masyarakat penggunaan Website DPMD yaitu pengguna merasa senang karena dapat memberikan banyak kemanfaatan dan pengguna menikmati menggunakan website. Kemudahan penggunaan website DPMD dan kemanfaatan dalam penggunaan website Dinas Pemberdayaan Masyarakat dan Desa Kabupaten Indragiri Hilir secara simultan berpengaruh signifikan terhadap sikap pengguna dalam penggunaan website. Kemudahan penggunaan website dan kemanfaatan dalam penggunaan website Dinas Pemberdayaan Masyarakat dan Desa Kabupaten Indragiri Hilir secara parsial berpengaruh signifikan terhadap sikap pengguna dalam penggunaan website DPMD. Variabel yang berpengaruh dominan terhadap sikap pengguna dalam penggunaan website DPMD yaitu Kemudahan penggunaan website.
\end{abstract}

Kata kunci: website, DPMD, indragiri hilir, TAM, informasi

\section{PENDAHULUAN}

Dalam perkembangannya, egovernment dipandang sebagai salah satu langkah dalam mewujudkan good governance di institusi pemerintah. Penelitian yang dilakukan oleh Karin Afriani, dkk (2009) 
membuktikan secara empiris bahwa implementasie-government oleh institusi pemerintah telah meningkatkan penilaian masyarakat terkait dengan prinsip-prinsip good governance yaitu kepedulian terhadap stakeholder, efektivitas dan efisiensi, partisipasi masyarakat, akuntabilitas, dan transparansi. Dalam literatur lainnya, Heeks (2002) mengatakan bahwa peran TIK dalam proses reorganisasi pada institusi pemerintahan sejalan dengan empat pilar agenda New Public Managemant (NPM) yaitu peningkatan efisiensi, desentralisasi, peningkatan akuntabilitas, perbaikan manajemen sumber daya, dan penciptaan mekanisme pasar [1].

Indonesia sendiri telah lama mengakui pentingnya e-government. Hal ini ditandai dengan ditetapkannya Instruksi Presiden (Inpres) Nomor 6 Tahun 2001 tentang Pengembangan dan Pendayagunaan Telematika di Indonesia yang memberikan instruksi kepada institusi publik di Indonesia untuk memanfaatkan teknologi informasi untuk mendukung good governance dan mempercepat proses demokrasi. Pada perkembangannya, kebijakan terkait pengembangan e-government kemudian ditetapkan melalui Inpres No. 3 tahun 2003 tentang kebijakan dan strategi nasional pengembangan e-government. Dalam Inpres tersebut, pengembangan e-government di indonesia bertujuan untuk menciptakan jaringan pelayanan publik berkualitas yang dapat dijangkau seluruh warga negara setiap saat, menciptakan hubungan interaktif dengan dunia usaha untuk meningkatkan kekuatan perekonomian nasional, menciptakan mekanisme dan saluran komunikasi antar lembaga negara, menyediakan fasilitas dialog publik bagi masyarakat agar dapat berpartisipasi dalam perumusan kebijakan negara, menciptakan manajemen pemerintahan yang transparan dan efisien, serta memperlancar transaksi dan layanan antar lembaga pemerintah [2].

Dalam menilai website yang berkualitas, berdasarkan prinsip dari good governance menyatakan website yang berkualitas apabila website tersebut menjalankan prinsip dari good governance yaitu transparansi, akuntabilitas dan efektif serta efesien. Sedangkan menurut Kementerian Komunikasi dan Informatika suatu website dikatakan berkualitas apabila website tersebut memenuhi kriteria yang telah ditetapkan yaitu tersedianya konten selayang pandang, pemerintahan daerah, geografi, peta wilayah dan sumber daya, peraturan atau kebijakan daerah, serta buku tamu dan berita. Dengan diterapkan unsur tersebut pada setiap web pemda, maka website pemerintah daerah akan berkualitas tinggi, insklusif, serta menampilkan citra yang berkaitan dengan kegiatan pemerintah [3].

Pada pemerintah Kabupaten Indragiri Hilir khususnya Dinas Pemerdayaan Masyarakat dan Desa (DPMD) Kabupaten Indragiri Hilir, penerapan website sistem informasi adalah suatu bagian yang tidak bisa dipisahkan. Peningkatan kualitas pelayanan publik adalah prioritas dalam pembangunan di Kabupaten Indragiri Hilir untuk agenda membangun pemerintah yang baik (good governance). Dalam menyelenggarakan pemerintahan yang baik dan bersih, diwujudkan dengan meningkatkan sistem informasi dan komunikasi pembangunan daerah yang didukung oleh pemanfaatan teknologi informasi untuk peningkatan kualitas pelayanan publik. Agar agenda tersebut tercapai, salah satu cara dilakukan diantaranya adalah optimalisasi pemanfaatan teknologi informasi dan komunikasi dalam pelayanan publik melalui website sistem informasi.

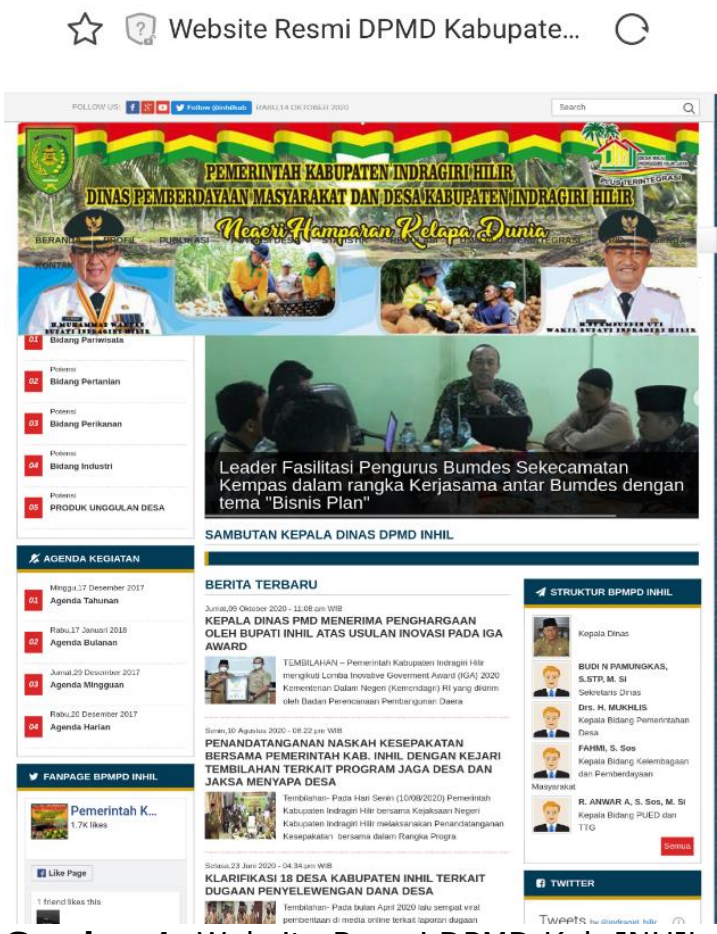

Gambar 1. Website Resmi DPMD Kab.INHIL

Agar website http://dpmd.inhilkab.go.id/ ini dapat diterima baik oleh pemakainya, maka perilaku menolak perlu diubah atau sistem perlu dipersiapkan terlebih dahulu. Merubah suatu perilaku tidak dapat dilakukan secara langsung ke perilakunya, tetapi harus dilakukan melalui penentu atau penyebab perilaku tersebut. Pengidentifikasian faktorfaktor penentu penerima / adopsi teknologi 
informasi menjadi hal penting untuk pengembangan suatu sistem informasi sehingga investasi yang tinggi terhadap fasilitas IT tersebut menjadi termanfaatkan dan mampu menciptakan nilai organisasi.

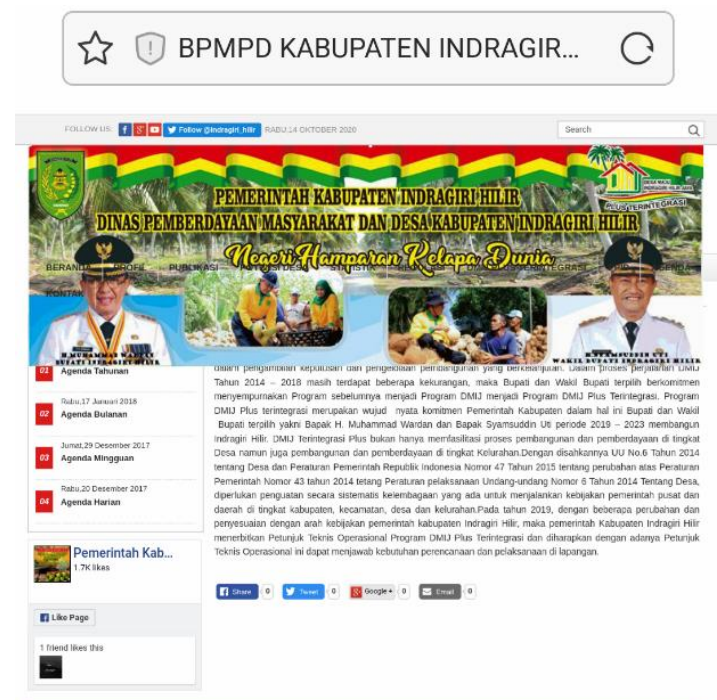

Gambar 2. Website Profile DPMD Kab.INHIL

Pada penelitian ini dilakukan pengukuran guna memprediksi penerimaan dan adopsi teknologi informasi khususnya teknologi internet pada masyarakat kabupaten indragiri hilir, dengan menggunakan pendekatan model penerimaan teknologi (Technology Acceptance Model / TAM) yang telah dikembangkan dengan menambahkan variabel pengaruh sosial (social influence) dan kemampuan diri (self-efficacy), yang menjadi penyebab (antecendent) perilaku selain konstruk TAM lainnya yaitu kegunaan persepsia (perceived usefulness) dan kemudahan pengguna persepsia (perceived ease of use) pada TAM.

\section{TINJAUAN PUSTAKA}

\subsection{E-Government}

E-government secara sederhana dapat diartikan sebagai bentuk pengiriman layanan kepada warga negara melalui internet. Sesuai dengan definisi dari World Bank (2011) yang banyak diunakan pada penelitian-penelitian sebelumnya, e-government diartikan dengan penggunaan TIK (seperti wide area network, internet, dan komunikasi bergerak) oleh lembaga pemerintah yang mempunyai kemampuan untuk mentransformasikan hubungan G2C (Government to Citizen), G2B (Government to Business), dan G2G (Inter-government relationship). Tidak seperti jenis komunikasi tradisional lainnya yang bersifat linier dan hierarkikal, e-government adalah komunikasi dua arah dan berkelanjutan antara pemerintah dengan warga negara.

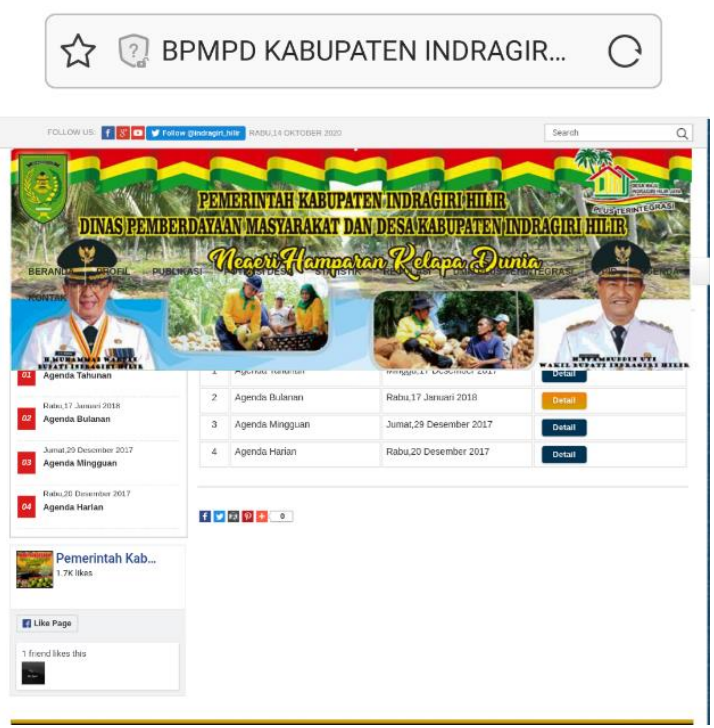

Gambar 3. Website Agenda DPMD Kab.INHIL

E-government mendefinisikan ulang hubungan antara pemerintah dan warga negara, sektor bisnis dan sektor publik dari 'commandand-control' menuju kolaborasi yang lebih interaktif. E-government mendistribusikan aktivitas yang sebelumnya sentralistik untuk memaksimalkan efisiensi, produktivitas dan penyediaan pelayanan. Dari definisi di atas, dapat disimpulkan bahwa terdapat dua tujuan utama dari e-government. Pertama, pemanfaatan TIK yang dilakukan oleh pemerintah diharapkan depat mendukung kebijakan efisiensi dan efektivitas layanan publik. Kedua, e-government diharapkan dapat menjadi media pemberdayaan masyarakat untuk berpartisipasi dalam pengambilan keputusan terkait kebijakan publik. Kesuksesan e-government dalam mencapai kedua tujuan tersebut dipengaruhi oleh setidaknya 20 persen teknologi dan 80 persen manusia, proses, dan organisasi (United Nation, 2012). Oleh karena itu, permasalahan utama dari e-government mencakup lebih dari sekedar teknologi, melainkan juga pada kesediaan warga negara untuk mengadopsinya [4].

\subsection{Peran Website dalam E-Government}

Website adalah sekumpulan halaman web (biasanya tedapat pada satu komputer) yang terhubung dengan internet dan menyimpan informasi dalam bentuk file-file hypermedia yang dapat diakses dari komputer lain dalam jaringan melalui link hypertext [5]. Dalam kaitannya dengan egovernment, peran website adalah sebagai sebuah sistem informasi yang menjadi antar muka (interface) mewakili kehadiran pemerintah selaku penyedia layanan publik di tengah-tengah warga negara. 


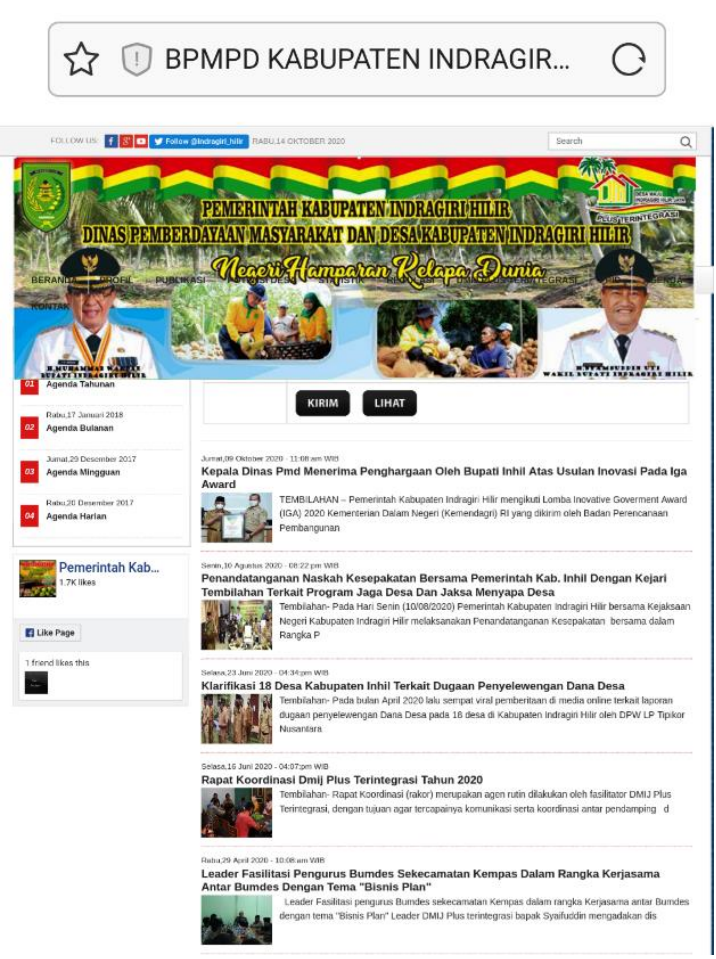

Gambar 4. Menu Publikasi DPMD Kab.INHIL

Dari website inilah segala bentuk layanan disampaikan oleh pemerintah dan dimanfaatkan oleh warga negara. Bentuk layanan yang disediakan dalam website dapat bermacam-macam, mulai dari jenis layanan yang sifatnya sederhana seperti informasi yang dapat dibaca oleh warga negara sampai pada layanan yang sifatnya kompleks seperti transaksi keuangan.

\subsection{Technology Acceptance Model (TAM)}

Technology Acceptance Model (TAM) merupakan salah satu model yang dibangun untuk menganalisis dan memahami faktor-faktor yang mempengaruhi diterimanya penggunaan teknologi komputer yang diperkenalkan pertama kali oleh Fred Davis pada tahun 1986. TAM merupakan hasil pengembangan dari Theory of Reasoned Action (TRA), yang lebih dahulu dikembangkan oleh Fishbein dan Ajzen pada 1980. TAM bertujuan untuk menjelaskan dan memperkirakan penerimaan (acceptance) pengguna terhadap suatu sistem informasi. TAM menyediakan suatu basis teoritis untuk mengetahui faktor-faktor yang mempengaruhi penerimaan terhadap suatu tekhnologi dalam suatu organisasi. TAM menjelaskan hubungan sebab akibat antara keyakinan (akan manfaat suatu sistem informasi dan kemudahan penggunaannya) dan perilaku, tujuan/keperluan, dan penggunaan aktual dari pengguna/user suatu sistem informasi. Model TAM yang dikembangkan dari teori psikologis, menjelaskan perilaku pengguna komputer yaitu berlandaskan pada kepercayaan (belief), sikap (attitude), keinginan (intention), dan hubungan perilaku pengguna (user behaviour relationship). Tujuan model ini untuk menjelaskan faktor- faktor utama dari perilaku pengguna terhadap penerimaan pengguna teknologi. Secara lebih terinci menjelaskan tentang penerimaan TI dengan dimensi-dimensi tertentu yang dapat mempengaruhi diterimanya TI oleh pengguna (user). Model ini menempatkan usage (penggunaan) sebagai dependent variabel, serta perceived usefulness (PU) dan ease of use (EOU) sebagai independen variabel. Kedua variabel independen ini dianggap dapat menjelaskan perilaku penggunaan (usage) [6].

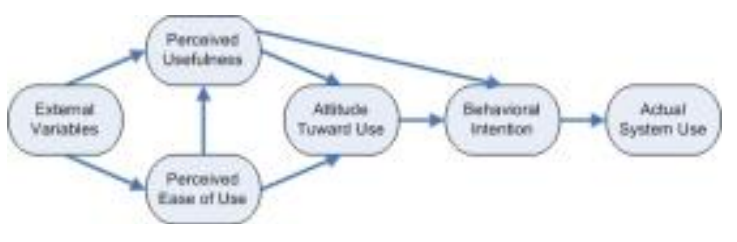

Gambar 5. Technology Acceptance Model (TAM)

TAM menggunakan TRA sebagai dasar teoritikal untuk menspesifikasi hubungan kausal antara dua kunci kepercayaan (belief) yaitu persepsi manfaat (Perceive Usefulness) dan persepsi kemudahan penggunaan (Perceieved Ease of Use). TAM jauh lebih spesifik dibandingkan dengan TRA, karena TAM ditujukan hanya untuk perilaku penggunaan teknologi komputer (Davis et.al, , 1986). Model TAM ini tidak hanya bisa untuk memprediksi, namun juga bisa menjelaskan sehingga peneliti dan para praktisi bisa mengidentifikasi mengapa suatu faktor tidak diterima dan memberikan kemungkinan langkah yang tepat. Tujuan utama dari Technology Acceptance Model (TAM) sesungguhnya adalah untuk memberikan dasar langkah dari dampak suatu faktor eksternal pada kepercayaan intern (internal beliefs), sikap (attitude) dan niat (intention). TAM dirancang untuk mencapai tujuan tersebut dengan cara mengidentifikasi beberapa variabel dasar yang disarankan pada penelitian sebelumnya yang setuju dengan faktor-faktor yang mempengaruhi secara cognitif dan affectif pada penerimaan komputer (computer acceptance) dan menggunakan TRA sebagai dasar teoritikal untuk menentukan model hubungan variabel penelitian. TAM memposisikan dua kepercayaan (beliefs), yaitu perceive usefulness dan perceieved ease of use sebagai faktor utama perilaku penerimaan komputer Dalam Technology Acceptance Model (TAM) dikenal ada 5 konstruk (Davis et. al, 1986), seperti terlihat pada Gambar 2 


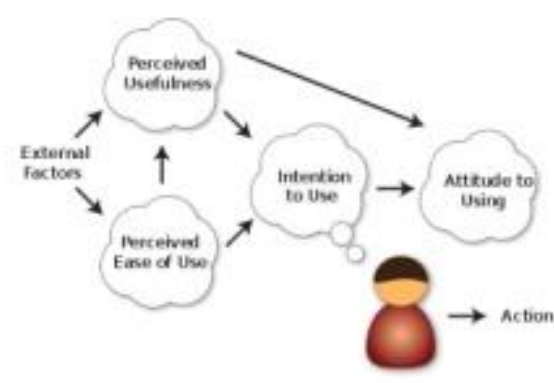

Gambar 6. TAM dan TRA Menurut Davis

Pada Gambar 2 dapat dijelaskan sebagai berikut (1) Persepsi kemudahan penggunaan (perceived ease of use), didefinisikan sebagai sejauh mana seorang percaya bahwa menggunakan suatu teknologi akan bebas dari usaha, (2) Persepsi kegunaan (perceived usefulness), didefinisikan sebagai sejauh mana seorang percaya bahwa menggunakan suatu teknologi akan meningkatkan kinerjanya, (3) Sikap terhadap penggunaan teknologi (attitude toward using), didefinisikan sebagai evaluasi dari pemakai tentang ketertarikannya dalam menggunakan teknologi, (4) Minat perilaku menggunakan teknologi (behavioral intention to use), didefinisikan sebagai minat (keinginan) seseorang untuk melakukan perilaku tertentu, (5) Penggunaan teknologi sesungguhnya (actual technology usage), diukur dengan jumlah waktu yang digunakan untuk berinteraksi dengan teknologi dan frekuensi penggunaan teknologi tersebut.

\subsection{Model Kesuksesan Sistem Informasi Website}

Di antara berbagai penelitian mengenai faktor-faktor keberhasilan sistem informasi website, model yang disarankan oleh Delone dan McLean telah menyita perhatian yang besar dari para peneliti. Model yang dikembangkan oleh DeLone dan McLean (1992) mengusulkan enam dimensi utama dari kesuksesan sistem informasi website yaitu kualitas sistem, kualitas informasi, penggunaan, kepuasan pengguna, dampak individual, dan dampak organisasi. Model ini memberikan dua kontribusi penting untuk memahami keberhasilan atas implementasi sebuah sistem informasi website. Pertama, model ini menyediakan sebuah skema untuk mengelompokkan banyak langkah-langkah sukses sistem informasi website yang telah digunakan dalam berbagai literatur. Kedua, model ini menunjukkan hubungan saling ketergantungan temporal dan kausal antar kategori. Dalam perkembangannya, para peneliti dibidang sistem informasi website mengajukan beberapa modifikasi terhadap model yang dikembangkan oleh DeLone dan McLean. Untuk mengakomodir usulan atas modifikasi tersebut, pada tahun 2003 DeLone dan McLean mengusulkan model yang diperbarui. Model yang diperbaharui tersebut dapat dilihat pada Gambar 3, perbedaan utama antara model asli dan model yang diperbarui adalah penambahan kualitas layanan untuk mencerminkan pentingnya layanan dan dukungan dalam sistem e-commerce yang sukses, penambahan niat menggunakan untuk mengukur sikap pengguna, dan penyederhanaan dampak individu dan dampak organisasi menjadi keuntungan bersih.

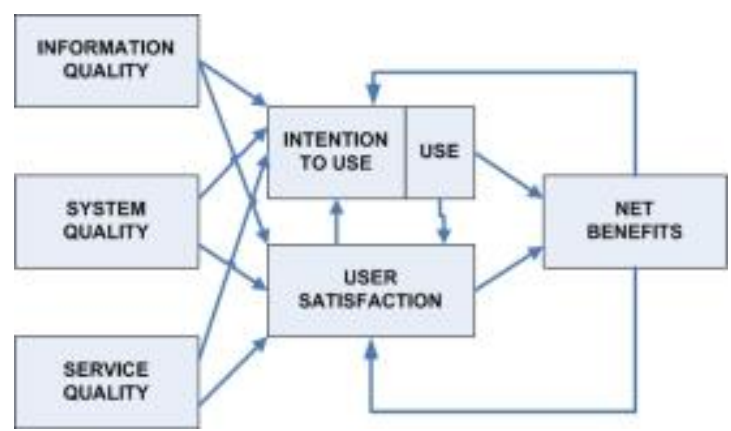

Gambar 7. Model Kesuksesan Sistem Informasi Website

Dengan demikian masing-masing variabel yang menggambarkan keberhasilan sistem informasi meliputi (a) Kualitas Sistem, Kualitas sistem merupakan karakteristik yang diinginkan dari suatu sistem informasi. Sebagai contoh adalah kemudahan penggunaan, fleksibilitas sistem, keandalan sistem, dan kemudahan belajar, (b) Kualitas Informasi, kualitas informasi merupakan karakteristik yang diinginkan dari output yang dihasilkan oleh sistem. Sebagai contoh adalah relevan, dapat dimengerti, akurat, ringkas, lengkap, tepat waktu, dan berguna, (c) Kualitas Layanan, kualitas layanan merupakan kualitas dukungan yang diterima pengguna dari organisasi dan personel penyedia layanan sistem informasi. Sebagai contoh adalah respon, akurasi, keandalan, kompetensi teknis, dan empati dari staf personalia, (d) Penggunaan Sistem, penggunaan sistem merupakan tingkat dan cara di mana staf dan pelanggan memanfaatkan kemampuan dari suatu informasi sistem. Sebagai contoh adalah jumlah penggunaan, frekuensi penggunaan, sifat penggunaan, ketepatan penggunaan, tingkat penggunaan, dan tujuan penggunaan. Mengingat kesulitan dalam menafsirkan aspek multidimensi dari penggunaan sistem, model ini juga mengusulkan agar niat untuk menggunakan dapat menjadi ukuran alternatif dalam beberapa konteks, (e) Kepuasan Pengguna, kepuasan pengguna merupakan tingkat kepuasan terhadap laporan yang dihasilkan, website, maupun layanan dukungan. Sebagai contoh adalah instrumen multi-atribut 
untuk ukuran kepuasan pengguna informasi, (f) Keuntungan Bersih, keuntungan bersih adalah sejauh mana sistem informasi berkontribusi untuk keberhasilan individu, kelompok, organisasi, industri, dan bangsa. Sebagai contoh adalah peningkatan kualitas pembuatan keputusan, peningkatan produktivitas, peningkatan penjualan, pengurangan biaya, keuntungan meningkat, efisiensi pasar, kesejahteraan konsumen, penciptaan lapangan kerja, dan ekonomi pembangunan [7].

\subsection{Sistem Informasi}

Menurut Kusrini, dkk (2007) sistem informasi adalah suatu sistem di dalam organisasi yang mempertemukan kebutuhan pengolahan transaksi harian, mendukung operasi, bersifat manajerial dan kegiatan strategi dari suatu organisasi dan menyediakan pihak luar tertentu dengan laporan-laporan yang diperlukan". Definisi umum sistem informasi adalah "Sebuah sistem yang terdiri atas rangkaian subsistem informasi terhadap pengolahan data untuk menghasilkan informasi yang berguna dalam pengambilan keputusan" [8].

\subsection{Internet}

Internet adalah sebuah solusi jaringan yang dapat menghubungkan beberapa jaringan lokal yang ada pada suatu daerah, kota atau bahkan sebuah negara. Internet juga diartikan sebuah jaringan yang terdiri dari berbagai macam ukuran jaringan komputer diseluruh dunia mulai dari sebuah PC, jaringan-jaringan lokal berskala kecil, jaringan-jaringan kelas menengah, hingga jaringan-jaringan utama yang menjadi tulang punggung internet seperti NSFNet, NEARnet, SURAnet, dan lain-lain. Jaringan-jaringan ini saling berhubungan atau berkomunikasi satu sama lain dengan berbasiskan protokol IP (Internet Protocol, RFC 793) pada network layernya (layer ke 3 dari 7 layer OSI model) dan TCP (Transmission Control Protocol, RFC 791) atau UDP (User Datagram Protocol, RFC 768) pada transport layer-nya (layer ke 4), sehingga setiap pemakai dari setiap jaringan dapat saling mengakses semua service atau layanan yang disediakan oleh jaringan lainnya [9].

\subsection{Website}

World Wide Web (WWW) adalah sebuah bagian dari internet yang sangat dikenal dalam dunia internet, dengan adanya WWW seorang pengguna dapat menapilkan sebuah halaman Virtual yang disebut dengan website. Sistem pengaksesan informasi dalam internet yang paling terkenal adalah World Wide Web (WWW) atau biasa dikenal dengan istilah Web. Pertama kali diciptakan pada tahun 1991 di CERN, Laboratorium Fisika Partikel Eropa, Jenewa, Swiss. Tujuan awalnya adalah untuk menciptakan media yang mudah untuk berbagi informasi diantara fisikawan dan ilmuwan. Web menggunakan protocol yang disebut HTTP (HyperText Transfer Protocol) yang berjalan pada TCP/IP [9].

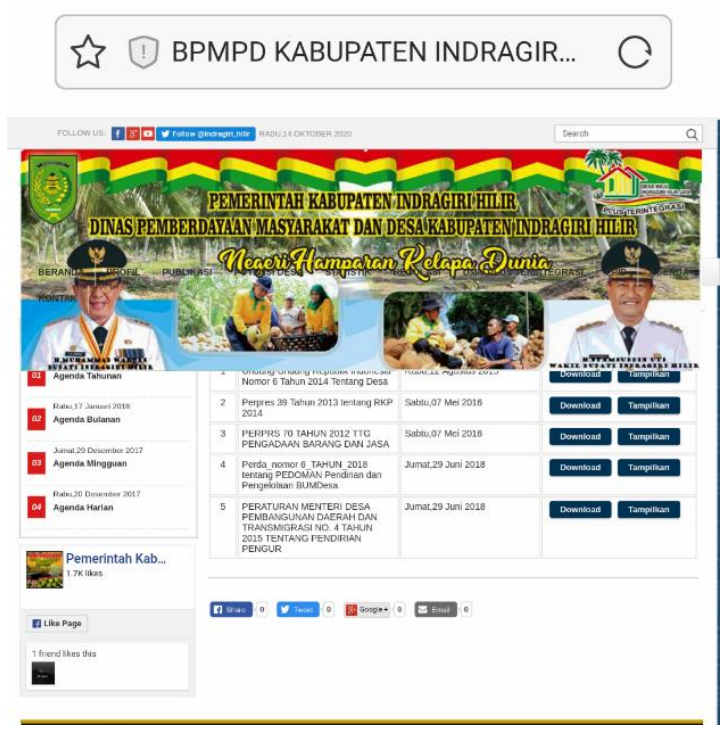

Gambar 8. Menu Regulasi DPMD Kab.INHIL

\subsection{URL}

URL (Universal Resource Locator) adalah petunjuk ke sumber daya tertentu di janringan TCP/IP (Internet). URL digunakan dengan software browser untuk menempatkan dan mengakses informasi di World Wide Web. URL terbagi menjadi beberapa bagian atau dikenal dengan istilah http://domain/path/filename, atau disebut pula metode akses - lokasi komputer lokasi file. Di antara bagian tersebut adalah (1) bagian pertama URL dikenal sebagai protokol atau disebut pula $h t t p: / /$ yang merupakan singkatan dari Hypertext Transfer Protokol, (2) bagian kedua dari URL dikenal sebagai nama domain, domain mewakili nama server yang sedang berhubungan dengan internet, (3) bagian ketiga dari URL disebut dengan directory path yang merupakan area khusus dimana item-item berada, (4) bagian keempat dari URL disebut nama file dokumen, ini menentukan file khusus yang sedang diakses. Biasanya adalah sebuah file $\mathrm{HTML}$, tapi mungkin juga gambar, suara atau file lainnya [9].

\subsection{Browser}

Browser adalah sebuah program aplikasi yang diperlukan untuk menjelajahi dunia maya internet. Aplikasi ini mempunyai kemampuan menampilkan suatu web page yang ditulis dalam bentuk dokumen HTML. Web browser membaca instruksi yang ditulis dalam html dan menggunakan instruksi tersebut untuk menampilkan konten halaman web dilayar Anda. Browser adalah sebuah software yang digunakan 
untuk mengakses/menampilkan halaman web. Browser berkomunikasi dengan server melalui protokol HTTP, yang membaca dan menerjemahkan bahasa HTML dan data lainnya dan kemudian menampilkan secara visual sehingga informasi yang ada dapat dibaca. Browser adalah Perangkat lunak untuk berselancar atau menjelajah di internet. Kemampuan dari sistem ini diantaranya adalah menampilkan informasi yang terdapat pada suatu alamat di internet serta menuju halaman lain yang terkait yang disediakan oleh halaman tersebut. Browser adalah program aplikasi yang menterjemahkan kode HTML dan merepresentasikan halaman website. Aplikasi inilah yang paling sering di gunakan setiap hari untuk melakukan browsing di internet. Browser yang baik memiliki kompatibilitas dalam membaca dan menerjemahkan script web, khususnya yang client side seperti javascript, Vbscript, CSS, XML, dan RSS dan dukungannya terhadap plug in seperti flash player, quicktime, java applet, dan sebagainya [9].

\section{METODOLOGI PENELITIAN}

Penelitian ini adalah penelitian kuantitatif dengan menggunakan rancangan penelitian kausal yang bertujuan untuk mendapatkan bukti sebab akibat antara variabel-variabel penelitian yang terdiri atas perceived ease of use, perceived usefulness dan attitude toward using. Dalam melakukan penelitian Penerimaan Informasi Pengguna Website dengan menggunakan Technology Acceptance Model

http://dpmd.inhilkab.go.id ini dibuat langkah-langkah penelitian sebagai alur pekerjaan penelitian. Dalam penelitian ini langkah penelitian tersebut dapat dilihat pada Gambar 9

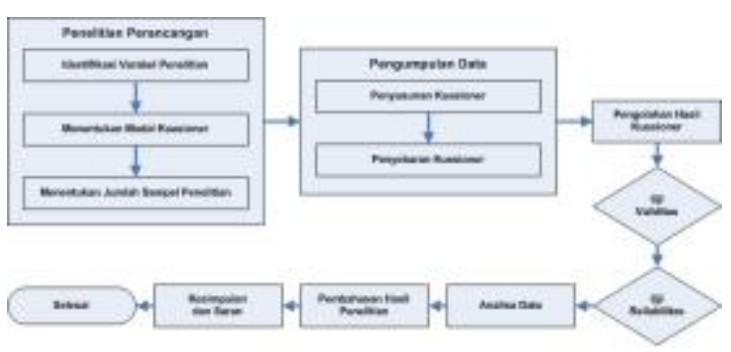

Gambar 9. Langkah-Langkah Penelitian

Pada Gambar 9 langkah-langkah penelitian dimulai dengan melakukan pendataan responden. Setelah menyebarkan kuesioner, kemudian data kuesioner dikumpulkan lalu dilakukan pengolahan data dengan menggunakan Software SPSS yang berdasarkan performance expectancy, effort expectancy, social influence dan facilitating conditions. Dari hasil tersebut menghasilkan kesimpulan dan setelah itu penelitian dianggap selesai. Di penelitian ini peneliti menggunakan sebuah model sebagai kerangka pemikiran teoritis yaitu TAM yang digunakan dalam penerimaan informasi pengguna website. Sesuai dengan ruang lingkup penelitian maka model TAM yang digunakan dalam penelitian ini telah dimodifikasi sedemikian rupa. Model penelitian tersebut memberikan gambaran bahwa ada pengaruh sejumlah faktor dari Perceived Usefulness (PU), Perceived Ease of Use (PEOU) terhadap Attitude Toward Using (ATU) yang selanjutnya akan dianalisis menggunakan software analisis SPSS.

Skala pengukuran dalam jawaban kuisioner yang akan digunakan pada penelitian ini adalah skala Linkert, dimana variable yang akan diukur dijabarkan menjadi indicator variabel. Kemudian indicator tersebut dijadikan sebagai titik tolak untuk menyusun item-item instrument yang dapat berupa pernyataan atau pertanyaan. Untuk keperluan analisis kuantitatif, maka jawaban itu diberi skor 1-5 yang didefinisikan sebagai berikut:

a) Sangat Tidak Setuju (STS) diberi skor 1,

b) Tidak Setuju (TS) diberi skor 2 ,

c) Ragu-ragu (RR) diberi skor 3,

d) Setuju (S) diberi skor 4,

e) Sangat Setuju (SS) diberi skor 5

Hipotesis dalam penelitian ini meliputi hipotesis umum dan hipotesis khusus. Hipotesis umum pada penelitian ini adalah

H1 : Tidak ada pengaruh Persepsi Kemudahan Pengguna (Perseived ease of use) (X1) secara signifikan terhadap Sikap Pengguna (Attitude Toward Using) (Y).

H2 : Tidak ada pengaruh Persepsi Kemanfaatan Pengguna (Perseived usefulness) (X2) secara signifikan terhadap Persepsi Sikap Pengguna (Attitude Toward Using) (Y).

\section{HASIL DAN PEMBAHASAN}

\subsection{Pengaruh Kemudahan dan Kemanfaatan terhadap Sikap Pengguna Website DPMD}

a. Uji F

Uji F dihitung untuk mengetahui apakah kemudahan penggunaan Website DPMD dan kemanfaatan Website DPMD secara simultan atau keseluruhan berpengaruh yang signifikan terhadap sikap penggunaan Website DPMD. Pengujian pengaruh secara 
simultan seluruh variabel bebas terhadap variabel terikat dengan uji $\mathrm{F}$ diperoleh $\mathrm{F}$ hitung $=111,175$. Sedangkan $F$ tabel 3,06 sehingga $F$ hitung $>F$ tabel. Sedangkan nilai probabilitas sebesar 0,000 lebih kecil dari $a=0,05(0,000$ $<0,05)$. Berdasarkan hasil probabilitas tersebut, maka $\mathrm{H}_{0}$ ditolak dan $\mathrm{H}_{1}$ diterima. Jadi kemudahan penggunaan website DPMB dan kemanfaatan website DPMD secara simultan berpengaruh signifikan terhadap sikap pengguna website DPMD.

\section{b. Uji t}

Uji t digunakan digunakan untuk mengetahui apakah kemudahan penggunaan Website DPMD dan kemanfaatan penggunaan website DPMD secara parsial berpengaruh signifikan terhadap sikap penggunaan website DPMD. Dari keseluruhan perhitungan menunjukkan bahwa nilai thitung adalah sebagai berikut

Tabel 1. Perbandingan $t_{\text {hitung }}$ dengan $t_{\text {tabel }}$ pada $a=5 \%$

\begin{tabular}{|c|c|c|c|c|}
\hline $\begin{array}{c}\text { Variabel } \\
\text { Bebas }\end{array}$ & $\begin{array}{c}\text { Koefisie } \\
n\end{array}$ & thitung & Sig. & Ket. \\
\hline $\begin{array}{l}\text { Kemudahan } \\
\text { Penggunaan } \\
\text { Website } \\
\text { DPMD }\end{array}$ & 0.490 & $\begin{array}{c}7,00 \\
2\end{array}$ & $\begin{array}{c}0,00 \\
0\end{array}$ & $\underset{n}{\text { Signifika }}$ \\
\hline $\begin{array}{l}\text { Kemanfaata } \\
\mathrm{n} \\
\text { penggunaan } \\
\text { website } \\
\text { DPMD }\end{array}$ & 0.168 & $\begin{array}{c}2,96 \\
7\end{array}$ & $\begin{array}{c}0,00 \\
3\end{array}$ & $\underset{n}{\text { Signifika }}$ \\
\hline
\end{tabular}

(Sumber: Data primer diolah, 2020)

Berdasarkan tabel 1 dapat diketahui bahwa kemudahan penggunaan website DPMD dan kemanfaatan penggunaan website DPMD secara parsial berpengaruh signifikan terhadap sikap penggunaan website DPMD. Untuk mengetahui variabel yang berpengaruh dominan terhadap sikap penggunaan website DPMD yaitu dengan melihat besarnya koefisien regresi, variabel yang memiliki koefisien terbesar dan signifikan terhadap sikap penggunaan website DPMD. Secara berurutan variabel yang berpengaruh terhadap sikap penggunaan website DPMD yaitu kemudahan penggunaan website DPMD dengan koefisien regresi sebesar 0,490 dan kemanfaatan penggunaan website DPMD sebesar 0,168. Dengan demikian, variabel yang berpengaruh dominan terhadap sikap penggunaan website DPMD yaitu kemudahan penggunaan website DPMD.

Berdasarkan hasil analisis, maka dapat digambarkan sebagai berikut :

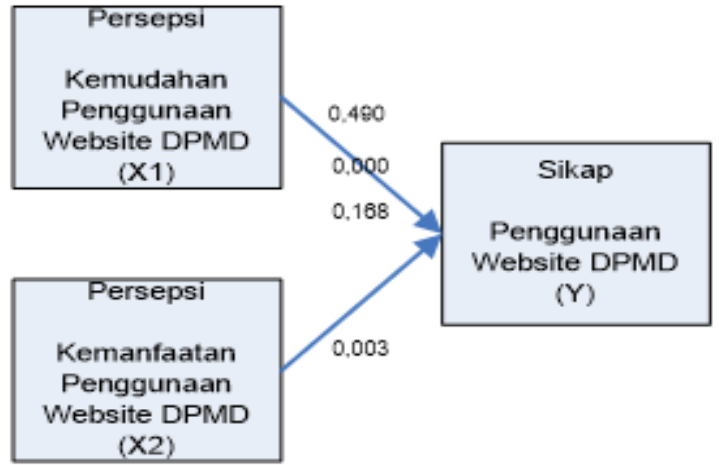

Gambar 10. Hasil Uji t

(Sumber: Data primer diolah, 2020)

\subsection{Pengaruh Kemudahan Penggunaan Website DPMD terhadap Sikap Penggunaan Website DPMD}

Kemudahan penggunaan website DPMD berpengaruh signifikan terhadap sikap pengguna dalam penggunaan website DPMD. Hasil penelitian ini konsisten dengan penelitian yang dilakukan Kumlasari (2010) yang menyatakan bahwa persepsi kemudahan berpengaruh langsung dan tidak langsung terhadap sikap penggunaan.

Persepsi kemudahan penggunaan mampu meyakinkan pengguna bahwa website DPMD mudah digunakan dan bukan merupakan beban bagi mereka. Website DPMD yang mudah digunakan akan terus dipakai oleh PEMDA Kab. Indragiri Hilir. Persepsi kemudahan penggunaan mempengaruhi kegunaan, sikap, minat prilaku dan penggunaan senyatanya. Kemudahan penggunaan (perceived ease of use) sebagai suatu tingkatan dimana seseorang percaya bahwa penggunaan sistem tertentu dapat mengurangi usaha seseorang dalam mengerjakan sesuatu. Intensitas penggunaan dan interaksi antara pengguna (user) dengan sistem juga dapat menunjukan kemudahan penggunaan. Website DPMD yang lebih sering digunakan menunjukkan bahwa sistem tersebut lebih dikenal, lebih mudah dioperasikan dan lebih mudah digunakan oleh penggunanya.

Hasil penelitian ini didukung dari jawaban responden yang menyatakan setuju bahwa Website DPMD mudah digunakan $(61 \%)$, pengguna merasa mudah mendapatkan apa yang dibutuhkan dari website DPMD $(45,3 \%)$ menyatakan sangat setuju, interaksi pengguna dengan website DPMD jelas dan mudah dimengerti (56.4\%) menyatakan setuju, pengguna merasa dengan website DPMD lebih praktis untuk berinteraksi $(50,6 \%)$ menyatakan sangat setuju, dan mudah bagi pengguna untuk menjadikan informasi saat menggunakan website DPMD $(65,1 \%)$ menyatakan setuju. 
Hal ini menunjukkan bahwa teknologi informasi merupakan bagian tak terpisahkan bagi pemerintah daerah kabupaten indragiri hilir terutama dalam era globalisasi saat ini. Dalam menghadapi era ini, kebutuhan produk-produk teknologi informasi menjadi kebutuhan dasar bagi pemerintah daerah kabupaten indragiri hilir untuk dapat menjawab semua dahaga informasi dari masyarakat kabupaten indragiri hilir. Perkembangan dan pemanfaatan teknologi informasi dewasa ini telah menyebar ke berbagai bidang dengan cepat.

Persepsi kemudahan menimbulkan percaya diri dan rasa aman dalam aktivitasnya sehingga seseorang bersedia meningkatkan penggunaan. Semakin mudah persepsi masyarakat dalam menggunakan website DPMD semakin besar tingkat percaya dirinya untuk menggunakannya. Venkatesh dan Davis (2000:201) membagi dimensi Persepsi Kemudahan Penggunaan menjadi berikut (a) Interaksi individu dengan sistem jelas dan mudah dimengerti (clear and understandable), (b) Tidak dibutuhkan banyak usaha untuk berinteraksi dengan sistem tersebut (does not require a lot of mental effort), (c) Sistem mudah digunakan (easy to use), (d) Mudah mengoperasikan sistem sesuai dengan apa yang ingin individu kerjakan (easy to get the system to do what he/she wants to do).

\subsection{Pengaruh Kemanfaatan Pengunaan Website DPMD Terhadap Sikap Penggunaan Website DPMD}

Kemanfaatan penggunaan website DPMD berpengaruh signifikan terhadap sikap pengguna dalam penggunaan website DPMD. Hasil penelitian ini menyatakan bahwa persepsi kemanfaatan (Y1) memiliki pengaruh langsung terhadap variabel sikap penggunaan (Y2). Hasil penelitian ini didukung dari jawaban responden bahwa melalui website DPMD pengguna mendapatkan informasi yang dibutuhkan $(58,7 \%)$ menyatakan setuju, dan melalui website DPMD pengguna mendapatkan informasi tambahan yang dibutuhkan (54,1\%) menyatakan setuju. Hal ini menunjukkan bahwa masyarakat memperoleh manfaat dengan menggunakan website DPMD. Persepsi kemanfaatan website DPMD memiliki pengaruh yang mendorong perilaku untuk menggunakan website DPMD, karena sebagai alat membantu masyarakat meraih berita yang bermanfaat dan memperoleh informasi valid yang dibutuhkan masyarakat. Persepsi kebermanfaatan penggunaan website DPMD merupakan pandangan subyektif masyarakat mengenai manfaat yang diperoleh oleh masyarakat guna meningkatkan kinerja masyarakat karena menggunakan website DPMD. Ketika masyarakat telah menggunakan website DPMD berkali-kali, maka masyarakat telah merasakan manfaat dari websiste DPMD tersebut. Sikap positif untuk menggunakan website DPMD timbul karena masyarakat yakin bahwa websiste DPMD dapat memberikan berita yang inovatif, jujur, valid dan terpecaya serta website DPMD bermanfaat bagi masyarakat kabupaten indragiri hilir.

\section{KESIMPULAN DAN SARAN}

Hasil analisis deskriptif tentang kemudahan penggunaan website DPMD menunjukkan bahwa pengguna mendapat kemudahan dalam menggunakan website DPMD yaitu kemudahan informasi saat dibutuhkan dan lebih praktis untuk berinteraksi. Kemanfaatan Penggunaan Website bagi pengguna website DPMD yaitu pengguna mendapatkan informasi yang dibutuhkan dan memperoleh informasi valid serta bisa dipercaya. Sikap Penggunaan Website DPMD yaitu pengguna merasa senang karena dapat memberikan banyak kemanfaatan dan pengguna menikmati menggunakan website DPMD. Kemudahan penggunaan website DPMD dan kemanfaatan dalam penggunaan website Dinas Pemberdayaan Masyarakat dan Desa Kabupaten Indragiri Hilir secara simultan berpengaruh signifikan terhadap sikap pengguna dalam penggunaan website DPMD. Kemudahan penggunaan website DPMD dan kemanfaatan dalam penggunaan website Dinas Pemberdayaan Masyarakat dan Desa Kabupaten Indragiri Hilir secara parsial berpengaruh signifikan terhadap sikap pengguna dalam penggunaan website DPMD. Variabel yang berpengaruh dominan terhadap sikap pengguna dalam penggunaan website Dinas Pemberdayaan Masyarakat dan Desa Kabupaten Indragiri Hilir yaitu Kemudahan penggunaan website DPMD.

\section{DAFTAR PUSTAKA}

[1] Afriani, Karin dan Fathul Wahid. 2009. Dampak e-government pada Good Governance: Temuan Empiris dari Kota Jambi. Seminar Nasional Aplikasi Teknologi Informasi 2009 (SNATI 2009). Yogyakarta.

[2] Inpres. 2003. Intruksi Presiden Republik Indonesia Nomor 3 Tahun 2003 tentang Kebijakan dan Strategi Nasional Pengembangan E-Goverment. Jakarta. 
[3] Khudri, Yusuf, Dwi Martani, Teguh I Maulana. 2013. Analisis Kualitas Desain dan Kunjungan Situs Pemerintah Derah Di Indonesia. Bandung.

[4] Yoserizal, Wahyu Eko. 2010. Strategi Pemerintah Provinsi Sumatera Barat dalam Mengembangkan eGovernment sebagai Upaya Peningkatan Kualitas Pelayanan Publik. Padang.

[5] McLeod, Raymond, Jr \& schell, George P, 2008, Sistem Informasi Manajemen, Edisi 10, Terjemahan oleh Ali Akbar Yulianto dan Afia R. Fitriati, Salemba Empat, Jakarta.

[6] Jogiyanto HM, 1990, Analisis \& Desain Sistem Informasi : Pendekatan Terstruktur : Teori dan Praktek Aplikasi Bisnis, Andi Offset, Yogyakarta

[7] DeLone \& McLean. 2003. Information System research, Journal of Management Information Systems, dan MIS Quarterly.

[8] Kusrini (2007). Tuntunan Praktis Membangun Sistem Informasi Akuntansi dengan Visual Basic \& Microsoft SQL Server. Yogyakarta: Andi Offcide.

[9] Nugroho, Bunafit, 2004, Aplikasi Pemrograman Web Dinamis dengan PHP dan MySQL, Gava Media, Yogyakarta. 